\title{
Stream Pollution Control in Indiana
}

\author{
Ralph B. Wiley \\ Head, School of Civil Engineering and Engineering Mechanics \\ Purdue University
}

The 1935 Indiana law placed the control of stream pollution under the Department of Commerce and Industry. A number of Indiana cities had installed sewage-treatment plarts voluntarily and a number of additional plants were constructed through the enforcement of this law. Unfortunately, the law was repealed when the Department was abolished in 1941 and no substitute was provided.

The 1943 law provided for the establishment of a Stream Pollution Control Board of six members with considerable authority. The Lieutenant Governor, the Director of the Department of Conservation, and the Secretary of the State Board of Health were made ex-officio members and the Governor was authorized to appoint three additional members; but no more than three members of the six-member board could be of the same political party. When the ex-officio members were of the same political party, the Governor was required to appoint three men of the opposite party. In 1945 the law was amended to increase the size of the board to seven and to give the Governor the power to appoint four, no more than two of whom should be of the same political party.

The present board consists of Lieutenant Governor Richard T. James; Milton Matter, Director of the Department of Conservation; Doctor L. E. Burney, Secretary of the State Board of Health, exofficio members; John Prout of the Noblitt-Sparks Company, Columbus, to represent industry; Anson Thomas of the Farm Bureau to represent agriculture; and Cecil K. Calvert of the Indianapolis Water Company and Ralph B. Wiley, Purdue University, Chairman, engineers.

Under the law all engineering assistance is furnished by the State Board of Health, and the Secretary of the State Board of Health has appointed B. A. Poole, Chief Engineer of the State Board of Health, as Secretary of the Stream Pollution Control Board. This arrangement has worked out very satisfactorily.

The three appointed board members holding offices at the end of Governor Schricker's term were reappointed by Governor Gates. 
Up to 1940 sixty-one Indiana cities with a population of $1,163,007$ had complete treatment, sixty-two per cent of the urban population; eleven (population 128,403) had primary treatment only, and nine (population 28,403) had septic tanks. Thus by 1940 the sewage of $70 \%$ of the urban population was receiving treatment of some kind.

The Stream Pollution Control Board in the last two years has issued orders against 35 cities and towns having a total population of 453,095 . This is $24 \%$ of the urban population. When all these plants are completed, the sewage from $86 \%$ of the urban population will be receiving satisfactory treatment, and that from $94 \%$ will be receiving treatment of some sort.

Twenty-three of the cities against which orders have been issued (population 413,705) have employed engineers and are proceeding with the work. Eight cities have already submitted preliminary plans, half of which have been approved. In one case the final plans have been approved.

Before 1940 seven industrial plants and twenty-four governmental institutions had treatment plants, and orders have been issued against seven industries and one school. Several state institutions have voluntarily begun work on plants.

The law specifically provides that the Board "shall have jurisdiction to control and prevent pollution in the waters of this state with any substance which is deleterious to the public health or to the prosecution of any industry or lawful occupation, or whereby any fish life or any beneficial animal or vegetable life may be destroyed, or the growth or propagation thereof prevented or injuriously affected." The Board is required "to determine what qualities and properties of water shall indicate a polluted condition . . ."

This has been done and, after a public hearing, the following Regulation was adopted:

WHEREAS, the Stream Pollution Control Board of the State of Indiana has the power under Section 7, Chapter 214, Acts of 1943 , to determine what qualities and properties of water shall indicate a polluted condition of such water in any of the streams or waters of this State, and

WHEREAS, the Board recognizes the fact that the character of all surface water is affected by the mode of life of the people and the activities of industry, and that both the people and industry are dependent on said surface water to a greater or lesser extent, and

WHEREAS, it is recognized that concentrations of population may exist on small streams where diluting water is insufficient to 
maintain suitable concentrations of oxygen by the use of known and reasonable methods of waste treatment, and

WHEREAS, there is a fair economic balance between cost of treatment of waste and benefits received beyond which it is not reasonable to expend money for treatment, and the cost of treatment and the benefits to be derived must be considered in determining the extent of corrective treatment to be applied, and

IVHEREAS, natural purifying agencies in the stream should be reasonably utilized, these agencies consisting primarily of the biology of the stream which is affected by the depth of the water, the velocity of the current, etc., and

WHEREAS, the necessary degree of purity of surface waters depends on the subsequent use which varies on different watersheds and at different points on the same watershed, and

WHEREAS, for the above-named reasons, each stream presents a separate problem and standards may need to be modified to fit specific cases,

BE IT RESOLVED, that in general the following regulations and standards shall be applicable to all receiving waters, and any water which does not meet such standards and properties shall be deemed and considered as in a polluted condition.

1. Floating material including grease and oil shall not be discharged into any surface water in deleterious amounts, or in amounts sufficient to affect injuriously fish life, fur bearing or domestic animals, or the general biology of the water, or plant life in or in the vicinity of such water.

2. Waste which is discharged into any water shall contain nothing which will deposit in a stream or a lake to form putrescent or otherwise objectionable sludge banks.

3. Waste which is discharged into any water shall contain no materials in concentrations sufficiently high to affect adversely public health, fish life, fur bearing or domestic animals, or plant life in or in the vicinity of such water.

4. Generally the oxygen content of the receiving water, after being mixed with and affected by the waste, shall be no less than 50 per cent saturation. A lower concentration will be tolerated temporarily, but only so long as it is not injurious to aquatic life, and in no case shall it fall below 25 per cent saturation.

5. Receiving waters shall be considered unsuitable for bathing if the coliform concentration exceeds 1000 per $100 \mathrm{ml}$. (MPN). If the receiving water is used as a source of water supply, a coliform density greater than 5000 per $100 \mathrm{ml}$. (MPN) shall not exist at or in the vicinity of the intake. Also in the case of wastes, bearing or producing substances objectionable from a taste or odor standpoint, which are 
discharged into waters which are used as a source of water supply, such wastes shall be so treated as to render them unobjectionable before discharge into the stream or lake.

The Technical Secretary is hereby directed to submit three (3) copies of the aforesaid rules to the Attorney General of Indiana, for his approval as to the legality of the same, and to then submit said copies to the Governor of Indiana, for his approval of the same, and thereafter file the original approved copy and one (1) duplicate thereof with the Secretary of State of the State of Indiana, and one (1) duplicate approved copy thereof with the Legislative Bureau of the State of Indiana.

This resolution was approved by the Attorney General and the Governor and was filed with the Secretary of State and the Legislative Bureau for publication with all other state regulations.

The law provides that a city or industry can appeal to the circuit or superior court from an. order of the Board. Either party can demand a jury trial. The court then has power "to determine whether said order is reasonable or unreasonable, and whether a polluted condition of any water or waters exists or is about to exist, and to affirm, modify, or wholly set aside such order, it being the intent and purpose of this act that the finding of said board as to whether a polluted condition of any water or waters exists or is about to exist is final only when so determined by the court." In every case the Board must first be prepared to prove that its order is reasonable and, second, that all the provisions of the law have been complied with.

The first step was taken by the adoption of stream-pollution standards. We feel certain that these are reasonable, but only a court decision can settle the matter. The Ohio River Compact, agreed to by Illinois, Indiana, Kentucky, New York, Ohio, Pennsylvania, Tennessee, and West Virginia, which has been approved by the Indiana Legislature, provides that

All sewage from municipalities or other political subdivisions, public or private institutions, or corporations, discharged or permitted to flow into those portions of the Ohio river and its tributary waters which form boundaries between, or are contiguous to, two or more signatory states, or which flow from one signatory state into another signatory state, shall be so treated, within a time reasonable for the construction of the necessary works, as to provide for substantially complete removal of settleable solids, and the removal of not less than forty-five per cent $(45 \%)$ of the total suspended solids: PROVIDED, That in order to protect the public health or to preserve the waters for other legitimate purposes, including those specified in Article I, in specific instances such higher degree of treatment shall be used as may be determined to 
be necessary by the commission after investigation, due notice and hearing.

All sewage or industrial wastes discharged or permitted to flow into tributaries of the aforesaid waters situated wholly within one state shall be treated to that extent, if any, which may be necessary to maintain such waters in a sanitary and satisfactory condition at least equal to the condition of the waters of the interstate stream immediately above the confluence.

The deputy attorney general who advises the Board is doubtful whether "substantially complete removal of settleable solids, and the removal of not less than forty-five per cent of the total suspended solids" would be held to be reasonable in all situations in an Indiana court. Under such a requirement all cities and towns could be required to install treatment plants regardless of size or amount of diluting water. Probably this is the ideal that we should strive for, but it would seem better to approach the matter more reasonably and to clean up the streams where we have positive evidence of pollution than to risk losing a case in court if we should proceed in an arbitrary way.

The first step in any action is to secure the data upon which a Board order is to be based. If samples show that the condition of the stream is below the standard set forth in the regulation, a preliminary order may be issued. Obviously such samples should be taken during periods of low stream flow. Lack of manpower and high flows during the past summer have materially restricted the activities of the Board, particularly when we consider that the easy cases have been taken care of (the sewage of $86 \%$ of the urban population). In future cases it will be necessary for us to collect the physical evidence that a city or industry is violating the regulations of the Board before definite action can be taken. The State Board of Health has recently been able to increase its engineering staff, and pollution studies will be speeded up.

Colonel M. E. Tennant, Deputy Attorney General, who is legal adviser for the Board, has set forth the various steps to be followed under the law as follows:

1. Board serves notice by registered mail that it has originally determined fact that city has violated provisions of Sec. 8 of Chap. 214, Acts of 1943 (Sec. 9).

2. Within 15 days of receipt of said notice, city may file a full report showing what steps are being taken to comply, or show cause why nothing is being done, or deny the fact of violation and file a petition asking a hearing on this issue of fact. (Sec.9.)

3. If hearing is requested, Board shall set date for hearing, not less than 10 nor more than 60 days after receiving petition, and serve notice of hearing by registered mail . (Sec. 9.) 
4. Hearing is held in summary manner. (Sec. 9.)

5. Within 15 days after hearing, final order is issued and served on city by registered mail. (Sec. 9.)

6. If city fails to comply with final order within 60 days, Board may commence action for enforcement of final order in Circuit or Superior Court. (Sec. 11.)

Colonel Tennant points out that the statute states that "the city may file a full report . . or deny the fact of violation . . ." but that in many cases there is no opposition and, therefore, no hearing. This has been true in most of our cases.

Municipalities may, if they choose, finance such projects by the issuance of "faith and credit bonds." But the law specifically provides as follows:

If the amount of such bonds necessary to be issued would raise the total outstanding bonded indebtedness of such municipal corporation ahove the said constitutional limitation on such indebtedness. or if such municipal corporation, by its common council or board of town trustees, as the case may be, should determine against the issuance of direct obligation bonds, then such municipal corporation shall issue revenue bonds and provide for the retirement thereof, in the same manner and subject to the same conditions as provided for the issuance and retirement of bonds in an act of the General Assembly of the State of Indiana entitled "An act to authorize cities and towns to construct, own, equip, operate, maintain, and improve works, for the treatment and for the disposal of sewage; to authorize charges against owners of premises for the use of such works and to provide for the collection of same; to authorize cities and towns to issue revenue bonds, payable solely from the revenues of such works, and to make such bonds exempt from taxation and to make them lawful investments of sinking funds; to authorize contracts for the use of such works by other cities, town and political subdivisions, and to authorize charges against owners of premises therein served thereby and declaring an emergency," approved August 17, 1932, as amended by Chapter 187 of the Acts of the General Assembly of Indiana, 1933, approved March 8, 1933, and as amended by an act of the 79th regular session of the General Assembly, such act as amended being sections 48-4301 to 48-432.3. inclusive, of Burns' Indiana Statutes, Revision of 1933, insofar as the provisions of said act, as amended, are applicable and are not in conflict with any of the express provisions of this act: PROVIDED, however, that the provisions of Section 5 of the above mentioned act, as amended, allowing objections to be filed with the common council or board of town trustees, by forty owners of property affected, and requiring the submission of the question of such bond issue and improvement to the qualified voters of such municipal corporation in certain cases, shall not apply to bond issues proposed by any municipal corporation to comply with a final order issued 
by the Stream Pollution Control Board under the authority of this act, and such objections and/or submission to the qualified voters of such municipal corporation shall not be authorized, nor shall the same, if had, operate to justify or excuse failure to comply with such final order.

The funds made available by the issuance of either direct obligation bonds or revenue bonds as herein provided, shall constitute a sanitary fund, and shall be used for no other purpose than for carrying out such order or orders of the Stream Pollution Control Board.

Steps have been taken to see that the entire procedure has the approval of a firm of bond attorneys, as it would be embarrassing to the Board to have such bonds declared illegal because some step in the necessary action was omitted or improperly taken.

All plans for sewage-treatment works, including sewers, must be approved by the Board.

In the case of the abatement of industrial pollution a difficulty arises when we find a case in which no one knows how to treat the waste. Fortunately, industry has come to recognize its obligations in the matter and several research projects have been set up that are being financed by industry.

The law provides that failure to comply with the final order of the Board constitutes a misdemeanor and makes the parties responsible subject to a fine of not less than twenty-five and not more than one hundred dollars, to which may be added imprisonment in the county jail for not more than ninety days.

The Board so far has received the hearty co-operation of all concerned. In many cases the city authorities have welcomed orders because they recognized that something should be done. 